F. von Benda-Beckmann, K. von Benda-Beckmann, E. Casino, F. Hirtz, G.R. Woodman and H.F. Zacher (eds.)

\title{
BETWEEN KINSHIP \\ AND THE STATE \\ Social Security and Law \\ in Developing Countries
}

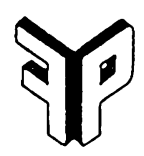

1988

FORIS PUBLICATIONS

Dordrecht - Holland/Providence RI - U.S.A. 


\section{Published by:}

Foris Publications Holland

P.O. Box 509

3300 AM Dordrecht, The Netherlands

Distributor for the U.S.A and Canada:

Foris Publications USA, Inc.

P.O. Box 5904

Providence RI 02903

U.S.A.

\section{CIP-DATA}

\section{Between}

Between Kinship and the State : Social Security and Law in Developing Countries / F. von Benda-Beckman ... [et al.] (eds.). - Dordrecht [etc.] : Foris

ISBN 90-6567-380-2

SISO 329.2 UDC 368.4(1.772/773)

Subject heading: social security ; developing countries.

Published for the Max-Planck-Institut für ausländisches und internationales Sozialrecht and the Commission on Folk Law and Legal Pluralism

The publication of this book was made possible by the financial support of the Max Planck Gesellschaft.

\section{ISBN 9067653802}

\section{1988 Foris Publications - Dordrecht}

No part of this publication may be reproduced or transmitted in any form or by any means, electronic or mechanical, including photocopy, recording or any information storage and retrieval system, without permission from the copyright owner.

Printed in the Netherlands by ICG Printing, Dordrecht. 


\section{Contents}

Preface

G.R. Woodman and H.F. Zacher

\section{GENERAL ORIENTATION}

Introduction: Between Kinship and the State

F. von Benda-Beckmann, K. von Benda-Beckmann, B.O. Bryde and F. Hirtz

Traditional Solidarity and Modern Social Security: Harmony or Conflict?

H.F. Zacher

Social Security in Third World Countries

M. Fuchs

\section{CHANGE IN LOCAL SOCIAL SECURITY SYSTEMS}

Person-Centered and State-Centered Social Security in Southeast Asia

E.S. Casino

The Decline of Folk-Law Social Security in Common-Law Africa G.R. Woodman

Traditional Systems of Social Security and their Present-Day Crisis in West Africa

R. Schott

Changing Relations Between Traditional and State Social Security in Taiwan

Chang Chih-Ming 
An Anthropological Perspective on Filial Piety versus Social Security

Choong Soon Kim

Changing Traditional Patterns of Social Security: Access to Land in Karo Batak Society

H. Slaats and K. Portier

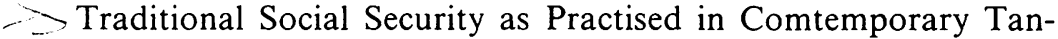
zania's Urban Centres

A.H. Bakari

Informal Social Security Among Moluccan Immigrants in the Netherlands

F. Strijbosch

\section{SOCIAL SECURITY AND LEGAL PLURALISM}

Formal and Informal Social Security in Ghana

A.K.P. Kludze

Formal and Informal Social Security - A Case Study of Tanzania A. Bossert

Social Security in a Peasant Society: The Case of Boyacá, Columbia J. Freiberg-Strauss and D. Jung

Coping With Adversity: Preliminary Research Findings on Social Security in the Rural Philippines

F. Hirtz

Support Among the Bakwena

A. Griffiths

The Situation of Unmarried Mothers and Their Children in

Tanzania: Protective Legislation and Social Reality

U. Wanitzek

Islamic Law and Social Security in an Ambonese Village

F. von Benda-Beckmann 
Bureaucrat-Client Interaction: Normative Pluralism in the Implementation of Social Security Disability Laws

$P$. de Koning

\section{LAW, POLITICS AND SOCIAL SECURITY STRATEGIES}

Social Security in the Context of French-African and Intra-African Labour Migration

O. Kaufmann

Dilemmas of Formal and Informal Social Security in Third World Countries: The Case of Egypt

A. Azer

Retribalization as a Strategy for Achievement of Group and Individual Social Security in Alaska Native Villages - with a Special Focus on Subsistence

S. Conn and S. Langdon

Social Security and Small-Scale Enterprises in Islamic Ambon K. van Benda-Beckmann

Social Security and Free Legal Aid in the Philippines

E.R. Pijuan

About the contributors 


\title{
Traditional solidarity and modern social security harmony or conflict?
}

\author{
Hans F. Zacher
}

\section{THE BASIC PATTERN OF MODERN SOCIAL SECURITY}

In order to explain the relationship between traditional solidarity and modern social security, it is useful to recall the pattern on which modern social security is based. (On the development of modern social security see: Köhler 1979; Köhler and Zacher 1981.)

The first element of this pattern is the specific structure of modern society. Basically, people live in small households - as parents with young and adolescent children, as married couples without children, or as single persons. The adults in such households generally earn money by working. If there are children, one of the adults - traditionally the wife and mother - may devote herself to looking after them, and perhaps not work outside the household and not earn an income.

The second element is the economy. This is characterised by the "division of labour". Production and distribution are functionally divided amongst various economic units (large and small companies, handicraft businesses, farms, etc.). In these economic units the work is again divided amongst the people who work in them. This division of labour entails incessant processes of exchange so that production and distribution bring about their eventual results. In this context, goods and services are exchanged for money (prices and wages).

This forms the basis for the evolution of modern social security (Zacher 1982). The development starts from the general rule that every adult earns a living for himself and his family (at any rate for the children and largely also for the spouse) by working (either as an employee or self-employed). The basic assumptions are: (a) that work provides income; and (b) that the income is adequate to meet the needs of both the income earner and his family. Within this context there are three central, potentially problematic areas.

1) Work and income: the organisation of work and earning of income by work. In the case where the individual has assets, he can, of course, substitute for income derived from work such income as he may gain by putting his capital to work or by consuming his assets. However, the phenomenon of the "capitalist" living on his capital is to be excluded 
from the following discussion. It is not a solution which is available to the broad masses. But the use of assets - particularly savings as a substitute for or a supplement to income when income from work is totally lacking or inadequate, is extremely significant from a social point of view.

2) The satisfaction of needs: the organisation of the production and distribution of goods which people need to meet their needs, such as food, clothing, housing, education, training and care. This can be performed by private enterprise or by administrative bodies, in the framework of "social market economy" or planned economy.

3) The support unit: group of persons who are interdependent or all dependent upon one of their number for the satisfaction of their inidividual needs. Normally the income of the wage earner is passed on to his dependants as support, in the form either of money or of goods purchased to satisfy the needs of the unit. Within the support unit, needs are also satisfied directly, the main example being a mother's care for her children.

The rule that each individual has social responsibility for himself and his nuclear family is realised in a dynamic process which comprehends these three areas. The rule is, of course, no more than a rule in the sense of a standard case and exceptions are both a possibility and a reality. The following social deficits are typical.

1) In the area of work and income a person may be unable to work completely or partly, permanently or temporarily, through sickness, invalidity, old age, etc. Alternatively a person may be unable to utilise his capability of working as in the case of unemployment. During the absence of the capability or while the capability cannot be utilised, there will be no income.

2) Social deficits occur with regard to the satisfaction of needs if a range of goods, such as housing, food or medical care, is so expensive that it is inaccessible to poorer people, or its purchase entails a disproportionately high burden for them. There are other emergency situations which have similar repercussions. For example, as a result of the level of development, a war or a catastrophe, certain goods may not be available at a given place or time. Or some groups in a society, discriminated against because of their race, religion or otherwise, may be denied access to the goods required to satisfy their needs. It is not imperative to discuss this at length here. 
3) With respect to the support unit, deficits occur in particular when one of the "useful adults" (the wage earner or the mother who looks after the children) is missing (e.g. because of death) or repudiates his obligations (e.g. refuses to provide support). The constitution of a support unit can also result in an insufficiency of income in relation to needs, if there is a disproportion between the numbers of actual wage earners and children in the unit, as in the case of families with numerous children.

These deficits constitute the central concern of measures in furtherance of social policy. To a certain extent it is reasonable to respond to the problems by measures in those areas in which they occur. For example, if a worker is prevented from working for a short time by sickness, it is reasonable for labour law to oblige the employer to continue to pay the worker's wage for this period. But there are limits. If, for example, a person is handicapped, and so permanently unable to work, labour law cannot reasonably oblige an employer to pay him a wage in perpetuity. The welfare state which wants to do justice to its concept has, in the final analysis, no alternative but to replace income derived from working by social benefits. Thus, from the start, there are two different types of solutions to the "natural" social problems we have described as social deficits:

- internalising solutions solve problems by acting in the areas in which they arise;

- externalising solutions solve problems by acting outside those areas. These solutions assign the function of compensating for social disadvantages to various bodies, some already existing, such as local government and state authorities, some created for this specific purpose, such as social insurance institutions.

Here are two examples:

1) Rules that protect the worker from occupational hazards are within the problem area of work and are a component of labour law. They are a priori internalising solutions. The consequences of work accidents, however, may be met with either an internalising or an externalising solution. Employer's liability is an internalising solution. Insurance of the employee against accidents at work is an externalising solution.

2) In the field of school education for children there is a danger of parents preventing their children from obtaining education. In this case, the 
solution is sought through rules of family law. A priori, this is an internalising solution in the problem area of the support unit. In contrast, a different form of the problem arises if the education system is organised in such a way as to disadvantage some children (e.g. those living in the country). Improving the school system is then an internalising solution within the problem area of need satisfaction. However, the provision of the parents or children with social benefits (family benefits, training, etc.) through the state or through a special fund in order to relieve them of some or all of the costs of the training would be an externalising solution.

Social security in the sense used here refers principally to externalising solutions. Modern social security has sought and found an increasing number of solutions to a core group of major, typical deficits: sickness, maternity, invalidity, old age, death leaving behind dependants, work accidents and occupational diseases, unemployment and family burdens through children. The principal solutions are:

- social insurance

- non-contributory schemes financed by taxation (demogrants)

- social compensation (for war victims, etc.)

- social promotion programmes (e.g. for families, for training promotion, for rehabilitation, etc.), and

- poor relief (in its more modern form known as social assistance).

As already mentioned above, services to meet certain needs in kind (e.g. for children, elderly persons, drug addicts, etc.) are part of a specific area lying between externalisation and internalisation. On the one hand they have the character of externalising solutions as they are taken over by the state, and on the other they are in the nature of internalising solutions because the specific social problem is inseparably embedded in a larger field of correlations.

The terms used in this context in various countries and eras are extremely ambiguous. This cannot be discussed at length here. But it is necessary to mention some modes of categorisation. Apart from the administrative "internalisation" of the satisfaction of needs (e.g. through a general education system, a general national health service), the arrangement of the various institutions involves the following questions in particular:

- The alternatives of services in kind and benefits in cash.

- The alternatives of individual allocation according to need (poor relief/ social assistance; depending on the nature of the treatment, generally 
also benefits of social work, care, medical attention, etc.); and allocation according to more generally determined standards such as according to contributions (as in the case of old age pensions of the social insurance system) and according to minimum or typical needs (as with flat rates, demogrants).

- The alternatives of provident provision against specified risks secured by contributions which entitle the person to future payments of benefits (social insurance); and tax-financed programmes rendering services and benefits to all citizens, inhabitants or similarly defined groups in all cases of specified need (demogrants, social services).

To achieve its aim of social security, the welfare state must nearly always combine several of these methods. An overall system of social security cannot be achieved by applying only the method of social insurance, only the method of poor relief (social assistance), or only the method of the demogrant. We nearly always find a combination of most varied methods: abstract standardisation of benefits and individual decision as to what is necessary; provident provision under which the size of benefits depends upon the income of the beneficiary as reflected in contributions, and provident provision according to typical conditions (demogrants); benefits which are defined by their social aims and benefits dependent upon a particular cause of loss (like provisions for war victims, crime compensation, or accident insurance). Unfortunately, "social security" is often identified with only one of these methods. This conceals the reality.

But we must also think back again to the close relationship between internalising and externalising solutions. This relationship is of major significance in the overall picture of a country's social security. Internalising and externalising solutions may be regarded as alternatives (as in the example of a worker suffering illness, where the "internalising" continued payment of wages by the employer is an alternative to the "externalising" sickness benefits of the health insurance scheme). They can be combined in sequence (taking the same example: the wage may continue to be paid for a time after which sickness benefits become payable). They can also be combined in parallel. Thus, to take another example, in the case of old age, a person may receive both an old age pension through the social insurance scheme (an externalising solution), and a pension from the employer (an internalising solution). The possible combinations can become even more sophisticated when taking into account that both private law and labour law also provide externalising solutions not mentioned so far. These are the private insurance or separate pension schemes (e.g. for old age) which employers may establish for their employees or trade unions for their members. Thus, in the case of old age a multi-layer system is 
possible: the basis a demogrant (e.g. a flat rate pension) funded by taxes; then a social insurance benefit or a benefit from an occupational system related to working income; then an employer's voluntary undertaking or an individual insurance contract supplementing the two other insurances.

In sum a "social security pluralism" has developed: a large number of methods and systems are employed to complement one another in the search for optimal results from a social, financial, administrative and legal point of view. Of course, there are differences between countries with a market economy and socialist countries. The latter, apart from the conferment of privileges on party officials, deserving revolutionaries, etc., have uniform systems in which the internalised solutions to social problems in the firms (i.e. also in labour law) play a major role (on wich see e.g.: Jahrbuch für Ostrecht 1979; Manz and Winkler 1985). In contrast, countries with market economies tend to have a greater variety of (mainly externalising) solutions (Zacher 1981).

In every case legislation is needed to organise and regulate all these different mechanisms (cf: Zacher 1984; Cranston 1985). Such legislation necessarily defines and thus standardises such aspects of life as sickness, invalidity, and old age. In real life all these phenomena have nebulous contours. When is a person ill or not ill? When is he or she able or unable to work? When is he or she old or not? However, social security systems tend to set up clearly defined limits in place of these flowing transitions. Thus social life meets with new structures and the behaviour of the individual is given a new orientation. New scope for individual choice of action evolves. Someone who is "slightly ill" must decide whether to continue to work and draw his wage or to claim he is ill and be paid sickness benefits. Someone who does not find quite the job he would like on the labour market must decide whether to accept work that does not appeal to him or to try to draw the benefits of the unemployment scheme.

This standardising of life by social legislation is at its most important in respect of marriage and the family. Social security systems cannot cover every possible definition of the support unit, neither can they cover every possible distribution of roles within this unit. Thus, questions such as whether a couple is married or not, to whom children in the household belong, and whether old people belong to the household, gain specific significance. Moreover, social legislation can change the situation within the family unit. In some circumstances the payment of an educational grant to a child tends to separate this child from the family unit. Payment of children's allowances to the head of the family increases the children's dependence. Generally we find that the laws referring to social security establish completely new structures and standards of behaviour for the life of the individual, and the groups and the society to which he or she belongs. 
The structures and processes of traditional solidarity are essentially different in every respect. ${ }^{\prime}$ Let us take the extreme case. In the archaic family, in the archaic village, in the archaic clan, in the archaic farm community, and indeed, in almost every pre-industrial urban household, the three areas of work and income, coverage of needs, and support largely coincide. The roles of the wage earner, the mother raising the children, and the recipient of support are not separated from one another as they are in the urban industrial society. Similarly the different phases of life are not clearly defined. Children of a young age and old people also join in the work; thus everyone contributes to the support of all.

The extent to which a community provides itself with the goods it needs or obtains them through exchange with other communities, depends on various circumstances: the form and size of the communities, the state of the economic system, and the degree of development of trade relations, especially the degree to which the barter economy has given way to a money economy. The development of civilisation also plays a considerable role. The more differentiated the needs are, the larger must be the units that cover these needs. This gives rise to questions about the internal structure of such units. This is not the place to analyse all these possibilities: the large unit in which a uniform authority assigns everyone as directly as possible a place; the stratified society which solves the problems by more or less strong contrasts of rule and subordination; or the complementary system in which the larger unit (the village or clan) does what the smaller unit (the family or domestic community) cannot afford. But in every case units of the size of present-day states mean relatively little for the daily social life of archaic societies.

The fact that, in archaic societies, the areas of work and income, of the satisfaction of needs, and of support largely coincide does not automatically imply that all needs are satisfied, that everybody has the same kind of needs, or that by working everybody makes the same contribution to the satisfaction of his and others' needs. The capacity of the unit sets an absolute limit which is generally not supplemented by any instance of what we would nowadays call national or international redistribution. Relative, internal differentiation results from power relations which, as history shows, can lead to extreme disproportions in the division of labour, in the satisfaction of needs and, last but not least, in the extent to which work may result in the satisfaction of needs. Archaic units are thus not necessarily egalitarian units. Moreover, by their very nature, archaic units by no means ensure that everyone finds a possibility of existence in them, and especially the possibility of an existence which we would today describe as being "worthy of a human being". 
Therefore, the archaic society is distinguished not so much by the same coverage of essential needs of the individual as by the fact that the ability to take up a normal, full working role does not entail the ability to earn what is necessary for oneself and one's family. Work is determined by social position and the satisfaction of needs is determined by social position.

The strict correlation between work, income, satisfaction of needs and support on the one hand and incapacity for work, absence of income, inability to satisfy needs and inability to provide support on the other, so characteristic of the industrial age until social security eased the situation, is unknown in archaic societies. Today we know that the rule of reciprocity or mutuality prevails in archaic societies. However, it does not generally operate over short periods of time, namely the working hour, working day, working week of working month, but rather is effective over phases of life. Anyone who does not work will in the long run be subjected to sanctions, which may take the form of a reduction in the satisfaction of his needs or in other social disadvantages, or punishments. However, anyone, such as a handicapped person, who always has greater needs than he himself can cover by working, will have his needs satisfied. The child has in his favour the expectation that he will be able to work later on, while the old person has the benefit of having worked all his life.

In the terminology used above to analyse modern social security we can say that archaic solidarity knows only "internalising" solutions for social problems. The distinction between the "internalising" and "externalising" solutions does not occur a priori. We can, indeed, go further and say that social problems as such do not become apparent in archaic societies. This is because the standards of work, of coverage of needs and of support are at the same time the social standards by which social deficits would have to be identified.

The social entities in which this takes place develop over a considerable time. Their rules are not positively made and laid down as are the rules of modern legislation. They are experienced by the society and its members. They may change with time, but there is no authority competent to change these arrangements. Law and moral principles are still largely one unit, and these rules are frequently also of a religious nature or determined by religious motives. Moral principles and religion, however, can change only by a process of development and not through instructions.

TRANSITIONS AND ENCOUNTERS

\section{The Transformation of Social Conditions}

As development occurs, however, the three areas of work and income, 
the satisfaction of needs, and support become ever more clearly separate. People work and earn in the town, in industry or in the service sector. Needs are determined and covered partly in the town, partly still in the village, partly by the public administration (e.g. as to schooling and medical care). The unit of support, the family, may remain intact, but it may also be temporarily split if, for example, most of the family remains in the village while one or more members move to the town to work.

As the areas of work and income, of the coverage of needs and of support separate, social deficits occur, such as were discussed at the outset in the context of modern social security. Thus, the units in which traditional solidarity was effective - the family, the village, etc. - are faced with a new and difficult challenge. While their control over the work and needs of their members decreases, they remain inescapably responsible for the satisfaction of the needs. They need to balance the work that individual members do outside, and the income thereby obtained by those individual members, together with the work that other members contribute within the system of the unit, against the needs, as they determine them, which require satisfaction inside and outside the unit. They also have to coordinate the demands for the new goods which development seems to make attainable with the access to the means to satisfy these new needs. The quicker the process of change and the incorporation of a society into this development, the greater is the social friction. During this process there are shifts in the structure of the society. Thus the importance of the village may decline and that of the family increase. This may solve problems, but it usually causes new ones, too.

The problems can also be seen from the aspect of the rules. The old, traditional, known rules answered the question of how work and the satisfaction of needs were to be allocated within the same unit. They do not answer the question of the allocation of earnings from work elsewhere and the satisfaction of the ever-increasing needs within the unit. If conditions change slowly, the old standards can be adjusted unobtrusively. However, conditions usually change so quickly that the answers given by the old rules no longer suffice, and there is little effort or it is just not possible to find answers to the new challenges in the spirit of the old rules. An important feature of the old standards is that they evolved, and were not made and laid down by a positive act. Thus, new answers to the new challenges would also need social consensus, and, indeed, one might even say new moral principles, to establish themselves.

Whether and to what extent new, efficient solutions come into being, depends on a number of circumstances, such as the nature of the developmental process, the relationship between town and country, the level of homogeneity or heterogeneity of the society, the power relations in the society, its creative power, and the external influences to which 
it is exposed. In addition, the religious background often plays a considerable role. The old standards usually concurred with the religion. What does the religion demand under the conditions of the new situation? Competition is liable to arise between the secular tendencies of the society and the religious forces, between politics and the representatives of the religion. The problem of religious fundamentalism affects the issue. Competition may also arise between various religions.

In real terms, the problems are expressed in the struggle of the old units to incorporate the new possibilities. Examples are the participation of the rural family in the wage of the member who earns in the town; the participation of the rural family in the new possibilities of satisfying needs which open up in the town; the participation of the rural family in the social benefits the town-dwelling member receives, but also the opportunity of the same member who has worked and earned in the town without breaking the link with the rural family to return to it when the town no longer offers him a possibility of subsistence.

However, the possibilities of solving the problems by forming new rules in the spirit of the old standards remain limited. Ultimately, the intervention of state-made law becomes inevitable (Zacher 1984; Cranston 1985). However, conversely this intervention is one of the reasons why the adjustment of social standards to the new situation no longer occurs autonomously. This applies particularly if the state pursues modernisation objectives through legislation, or tries to change social values. (See e.g. Schaeffer 1983; Bryde and Kübler 1986.) Thus, for example, the state intervenes in some African countries to improve the position of women (UNECA 1982). But whatever the reasons may be, once this intervention of state-made legislation occurs, the legislative rules come into competition with the social rules. The result can be harmony or conflict, reciprocal complement or reciprocal paralysis. In any case the development produces an increasing concentration on the responsibility of state-made legislation, of the state courts and authorities. Even when the state endeavours to preserve the old contents of traditional solidarity - or at any rate rather than abolishing them tries to develop them - the technique of regulation is nevertheless increasingly modern.

\section{The Difficulties of Modern Social Security}

Modern social security also is faced with difficulties during the state of development. ${ }^{2}$ It is confronted with various forms of social life which it is not adapted to service. Modern social security takes as its preconditions such factors as the compactness of the nuclear family, the clear division of roles in the small family, and the full-time work of the wage earner. However, in social orderings which follow upon the dissolution or change 
of traditional solidarity, the most varied arrangements are found.

The transition in a country from archaic social conditions and traditional solidarity to a modern, industrial, urban society with the basic starting points for the methods of modern social security, is always linked with often widely differing technological, economic and social conditions in that country. However, modern social security requires a certain minimum set of living conditions. Let us take a closer look at the character of modern social security.

- First, social security fundamentally aims to maintain social normality. All social security measures, whether for sickness, maternity, invalidity, old age, accidents at work, occupational diseases, unemployment, death of the wage earner, or large numbers of children, are nothing else than attempts to prevent or at least reduce the drop into subnormality. This drop threatens if, as a result of any such occurrence, a person's income fails to materialise, the need for medical treatment or such like constitutes an unbearably high burden, support to dependants ceases, or there is too large a discrepancy between the income of the wage earner and the needs of dependants in a family with a large number of children.

- Secondly, poor relief (social assistance) is oriented towards those living in a state of subnormality. It provides a minimum of help in order to prevent subnormality from degenerating into the utter misery of starvation, hypothermia, etc. However, poor relief can operate thus as an element in modern social security only as long as such subnormality is exceptional.

- Thirdly, in fully developed welfare states some benefits aim to secure equal access to normality or to improve the positon of the individual within the range of normality. These are in particular the provision of or assistance with training, and the opportunity to acquire educational and professional qualifications. However, these also require that the enjoyment of these facilities should be available to the majority of people, that is, should be a characteristic of the social normality towards which the benefit programmes are oriented.

Thus, there needs to be a broad range of normality on the basis of which the social deficits can be identified and to which definitions of need, capacity to make provision, the appropriate level of benefits, etc. can be related.

This premise causes difficulties for systems of social security even in developed countries if living conditions - such as in the USA - are extremely divergent. These problems are, however, even more serious in countries 
where the scale of socio-economic conditions ranges from the rural subsistence economy of modest, archaic communities to the living conditions of an urban society which are affluent by any international standards. The range of variation is wide not only in terms of the division of labour and the differentiation of work and income. It also concerns the levels of needs and the possibilities of satisfying them. Indeed, it concerns the entire mode of life and standard of living.

Thus, there is not a single "normality" but many "normalities" of working relationships, support units, needs, and possibilities of satisfying needs, and in particular of incomes. This variety can be so extensive and significant that no system of modern social security can satisfactorily accommodate it. It is also impossible to meet this variety by providing a corresponding variety of systems of modern social security. There are two main reasons. First, the various social relationships are not differentiated enough. Family ties as well as spatial and social mobility incessantly intermingle the most different "normalities". The "normalities" are not compartmentalised in such a way as to permit the setting up of separate systems of social security for each one of them. Secondly, these social conditions which are similar to the archaic community where work and the satisfaction of needs are concerned are opposed to the specific techniques of modern social security in direct proportion to their similarity to that archaic community.

There is a further difficulty. Modern social security requires a minimum level of economic development, if not of prosperity. Therefore, economic conditions often make the use of techniques of modern social security difficult even when, according to the social circumstances, they might be possible, such as in the urban, industrial sector.

\section{SOLUTIONS}

Experience shows that methods of modern social security in developing countries can, generally, reach and protect only a relatively small proportion of the population, and this hardly the poorest. Indeed, modern social security in, for example, Latin America, is often a privilege of the middle classes, whose political position enables them to push through systems of social security for themselves and whose economic situation enables them to contribute to the financing of the provisions set up for them. (See the classic Mesa-Lago 1978.) Modern techniques of social security should therefore be seen as only one element in a comprehensive strategy of social security adapted to the particular conditions of developing countries. This strategy must be "social security pluralism". We already know this phenomenon from the industrialised countries. In the encounter and transition between archaic solidarity and modern social security it 
gains a quite new dimension (see e.g. Bossert 1985). While the social security pluralism of the industrial nations exists within a single normality, it is important here to take account of the different types of normality.

The construction of social security pluralism needs to refer to an Archimedian point to avoid confusion among the variety of "normalities". This may be found by considering the different bases of the various relationships. These are the individual, the family, the clan, etc. This means that internalising solutions should be used as far as possible, before externalising solutions. Internalising solutions specifically relate to the normality in which the individual and his closest relatives live. Externalising solutions, in contrast, tend as a result of their generality to miss the normality which determines the life of the individual.

What does this strategy of social security pluralism through internalisation mean in concrete terms? First of all, it means that the elementary units of social solidarity in which people work and meet their needs, such as families, village and clan communities, have to be strengthened and stabilised. Their ability to subsist must be promoted. Depending on the circumstances, expedient measures can be, for example, land reform, agricultural instruction, provision of seed after poor harvests, or replacement of livestock in cases of epizootic disease. In parallel, the open and differentiated interplay of roles according to which work is divided, and according to which needs are satisfied, should not rashly be destroyed through standardising regulation, such as is associated with modern social security.

The preservation and promotion of the ability to subsist do not suffice. It is also necessary to help these communities to find and realise their rules in the changing conditions. They have to master the changes in economic and social conditions, in particular by enabling their members to take initiatives in seeking work and income outside their own economic unit, but also in gaining access to new material and cultural possibilities of consumption, education, medical care, etc. At the same time, however, they also have to master changes in social values, such as the development of claims to equality of women, or to the emancipation of the individual. Social entities are by now not really able to decide on new rules. But this should necessarily materialise. Cooperative structures especially could often be a solution. But state laws and courts also are still faced with the task of finding or helping to find new rules which will tend to preserve the substance of the old units. They have the task of making effective these new rules against those who try to withdraw from the old units by exploiting the mobility now given to the individual. Customary courts often witness these problems and are at the same time an important instrument for solving them. In African countries in particular they are often used to clarify the position of women, children, the disabled and 
the aged in a changing community (e.g. Doumbé-Moulongo 1972; Mignot 1982; Meyer 1986).

On the other hand, wherever modern working life - and so also the separation of work from the coverage of needs - has developed, it is necessary to establish the protection of modern social security. Social deficits as a result of sickness, invalidity or old age have their special form and scope in the modern working world. Even if the background of a family or village subsistence community still exists, the risks of these social deficits can and should no longer be borne by it (Fuchs 1983, 1985; Zöllner 1983).

In these circumstances externalising solutions are both possible and necessary. However, experience shows that internalising solutions of an appropriate type are of special significance. The normality for a wageor salary-earning employee is determined primarily by his employment. The special security systems established for the civil service, the armed forces and similar institutions, have always shown this. However, even private firms' security systems for pensions in old age, continued payment of remuneration during sickness, and medical care by the firm or at the firm's expense are far more widespread in developing countries than in industrial nations (Nkanagu 1985). And even if externalising solutions are employed, the advantage of income-related social insurance, financed by contributions, and related to the specific normality of each person insured, is obvious.

Certain needs cannot be satisfied for large sections of the population unless particular, planned provision is made. School education and medical care are notable examples. In order to bring these services by appropriate degrees within the "normality" of the individual, and to coordinate them with the "normality" of his family, administrative organisation and presentation are generally required. This applies in particular to the need to differentiate services in terms of their adaptability to the various living conditions to which they are to be applied - a process which can best be carried out through a centrally planned but structured organisation. The "concentric" arrangement of health services with hospitals in the centres and health stations with simply trained staff on the periphery is an example. Here again the solution is "internalising", not now in the working world, nor in the subsistence unit, but in the administrative organisation. Social inequality in access to school education and medical care can be overcome, if at all, only if the state makes these services available.

These considerations suggest a picture of polarity between the rural subsistence economy and the urban economy with its division of labour in which administrative services (such as the education and medical systems) link the two poles. This picture is both right and wrong. It is right for elementary orientation. And it is wrong in that it conceals the locations of various living conditions between the two poles and the extent of 
population drift between them. This is exactly where the challenge of social security pluralism lies. Overcoming this difficulty is largely the function of informal social processes (Bossert 1985, and references therein). For example, the social security which an invalid or old person obtains at the end of his working life in the town frequently does not suffice to live there. Consequently he returns to the rural subsistence economy from which he originally came when he was seeking work in the town, and where the monetary benefit of his social security may be worth more. A whole range of informal processes keeps this possibility open for the future. Transfers and communications pass in both directions throughout the working life. The results seem to be accidental in the individual case. The entire process, however, can turn out to be an expedient balance between the performance capacity and the insufficiency of the modern social security on the one side and of the rural subsistence community on the other. Whether state regulation could achieve more in this case than social rules and the parties' responses to their own interests, can be doubted.

There have, however, been noteworthy attempts to facilitate the link between the formal and informal systems of traditional solidarity. Mention should be made here of the provident funds which play an important role in providing security for old age in numerous developing countries (Fuchs 1985: 27 et seq.). These are compulsory savings institutions. The social security they offer consists of the repayment to the individual of the amount saved at retirement age, or sometimes in the event of invalidity. They combine a minimum of externalising with a maximum of internalising. They provide the person leaving working life with a chance of buying his way back into his subsistence community with this capital or of otherwise securing a minimum standard of provision (as, for example, through the purchase of housing, or animals, or through the acquisition of a modest income from a craft or trade). This should not obscure the facts that provident funds are a cheap solution for policy purposes and are easily misused. Nevertheless, they allow a certain flexibility in the boundary between working life and subsistence, and thereby point out the natural aspect of the phenomenon.

In quite another way administrative systems of medical care frequently make use of special features of traditional solidarity. For example, Tanzania has an administratively organised health service. However, it does not assume the costs of transportation of patients from the village to the health station (Bossert 1985: 174). That is the responsibility of the village community. The latter seems to be the right body to judge the necessity of reimbursing the transportation costs. A fascinating example of a linking of administrative health care to traditional solidarity can be found in Mexico. Here social security is assured for the case of sickness as a matter of principle through a scheme of sickness insurance, the service being thus 
financed by contributions. But monetary contributions are not possible in the subsistence economy sector. Here for the payment of contributions is substituted the performance of services with which the local health station is provided. The local community allocates the duties of performing these services (Prieto 1969). While it is impossible to evaluate here the effects of this system, it may be seen that it is a remarkable attempt to link traditional solidarity with modern social security However, this strategy does not meet the problem of people for whom social security can be provided neither by a subsistence community nor by their working life. Examples are the urban unemployed, destitute invalids, homeless children, and slumdwellers. It is obvious that their problems can be solved by society only if they are incorporated into a work process, a subsistence economy, or a combination of both (e.g. National Center Cairo 1982). It is for this reason that the notion of social security for the case of unemployment causes misgivings which go far beyond the problems of financing. Indeed, social security against unemployment has remained especially unacceptable to the developing countries. However, something has to be done about the want in which people in the present category live. Provided the economic and administrative strength of the community suffices, the appropriate technique of social security is that which in industrial nations is designed to help people in subnormal conditions, namely, poor relief (social assistance). However, it is a fact that in many countries this is not "subnormal", but is the "normal" condition of want. This demands independent solutions. Organised (administrative or voluntary) services are somewhat more likely than monetary benefits to help the "subnormal normality" of these people without threatening the other "normalities" of the working life, the subsistence economy, etc.

\section{FINAL REMARKS}

As is so often the case in other respects, developing countries have a special burden to bear in the field of social security. Merely taking over the techniques of modern social securit: has proven a failure. Although they are useful. in doed indispensable, for a part of the society, this is largely the better off part. Moreover, these techniques are such that the advantages of this form of social security are generally greater, the better the recipients' social position already is. A more comprehensive social policy, however, is faced with the difficulty of the variety of conditions. This hardly permits completely satisfactory harmony. Nevertheless, there is no alternative to perseverance in the search for means to achieve in each society as much correspondence as possible of the methods of social security with the various normalities of the society. 
The industrial nations cannot offer a model that can simply be adopted by the developing countries. But I suggest that in the notion of the complementary nature of externalising and internalising solutions we may find a basis for discussion in which industrial and developing countries may combine their experiences most beneficially.

\section{NOTES}

1. On the concept of solidarity see Kaufmann 1984. On the subject-matter of this section generally see e.g. Partsch 1983.

2. On the following see e.g. Fuchs 1983, 1985; Zöllner 1983.

\section{REFERENCES}

Bossert, Albrecht 1985 Traditionelle und moderne Formen sozialer Sicherung in Tansania. Eine Untersuchung über Entwicklungsbedingungen. Berlin: Duncker \& Humblot.

Bryde, Brun-Otto, and Friedrich Kübler (eds.) 1986 Die Rolle des Rechts im Entwicklungsprozess, Schriftenreihe der Gesellschaft für Rechtsvergleichung, No. 134, Frankfurt/Main: Alfred Metzner.

Cranston, Ross 1985 Legal Foundations of the Welfare State. London: Weidenfeld and Nicolson. Doumbé-Moulongo, Maurice 1972 Les coutumes et le droit au Cameroun. Yaoundé: CLE. Fuchs, Maximilian 1983 "Der Stand der Forschung auf dem Gebiet des Sozialrechts in den Entwicklungsländern", Vierteljahresschrift für Sozialrecht 11: 5-19.

Fuchs, Maximilian 1985 Soziale Sicherheit in der Dritten Welt. Zugleich eine Fallstudie Kenia. Baden-Baden: Nomos.

Jahrbuch für Ostrecht 1979 Vol. 20: Faude, Strukturelemente sozialistischen Sozialrechts am Beispiel des Altersrentenrechts in der DDR and der UdSSR, 105-144; Florek, Das polnische Sozialversicherungssystem, 145-166.

Kaufmann, Franz-Xaver 1984 Solidarität als Steuerungsform - Erklärungsansätze bei Adam Smith, in: Franz-Xaver "Kaufmann and Hans-Günter Krüsselberg (eds.), Markt, Staat und Solidarität bei Adam Smith". Frankfurt/Main and New York: Campus, 158.

Köhler, Peter A. 1979 "Entstehung von Sozialversicherung. Ein Zwischenbericht", in: Hans F. Zacher (ed.), Bedingungen für die Entstehung und Entwicklung von Sozialversicherung. Berlin: Duncker \& Humblot.

Köhler, Peter A., and Hans F. Zacher 1981 "Sozialversicherung: Pfade der Entwicklung", in: Peter A. Köhler and Hans F. Zacher (eds.), Ein Jahrhundert Sozialversicherung. Berlin: Duncker \& Humblot.

Manz, Günter, and Gunnar Winkler 1985 Sozialpolitik. Berlin DDR: Verlag die Wirtschaft. Mesa-Lago, Carlo 1978 Social Security in Latin America. Pressure Groups, Stratification and Inequality. Pittsburgh: University of Pittsburgh Press.

Meyer, M.P. 1986 "La structure dualiste du droit au Burkina: problèmes et perspectives", Recueil Penant: 77-89.

Mignot, Alain 1982 "La justice traditionnelle, une justice parallèle, l'exemple du Sud-Togo", Recueil Penant: 5-30.

National Center for Social and Criminological Research, Cairo 1982 Development Potential and Low Levels of Living. A Pilot Study. (Manuscript - typescript circulated, 1985). 
Nkanagu, Tharcisse 1985 "Die afrikanische Erfahrung in Krankenversicherung und Gesundheitschutz im Rahmen der sozialen Sicherheit", Internationale Revue für Soziale Sicherheit XXXVIII: $131-154$.

Partsch, Manfred 1983 Prinzipien und Formen sozialer Sicherung in nicht-industriellen Gesellschaften. Berlin: Duncker \& Humblot.

Prieto, Ignacio Morones 1969 "Betrachtungen über den Umfang der sozialen Sicherheit in Mexiko", Internationale Revue für Soziale Sicherheit XXII: 220-233.

Schaeffer, Eugène 1983 "Die Entwicklung des afrikanischen Rechts zwischen Tradition und Entfremdung”, Jahrbuch für Afrikanisches Recht 2: 107.

UNECA (United Nations Economic Commission for Africa) 1982 Répertoire des mécanismes nationaux, sous-régionaux et régionaux pour l'intégration de la femme au développement en Afrique.

Zacher, Hans F. 1981 "Sozialrecht und soziale Marktwirtschaft", in: Im Dienst des Sozialrechts. Festschrift für Georg Wannagat zum 65. Geburtstag. Köln: Heymanns, 715.

Zacher, Hans F. 1982 "Zur Anatomie des Sozialrechts", Die Sozialgerichtsbarkeit 29: 329337.

Zacher, Hans F. 1984 "Verrechtlichung im Bereich des Socialrechts", in: Friedrich Kübler (ed.), Verrechtlichung von Wirtschaft, Arbeit und sozialer Solidarität. Baden-Baden: Nomos, 11.

Zöllner, Detlev 1983 "Sozialversicherung in den Ländern der Dritten Welt", Vierteljahresschrift für Sozialrecht 11: 21-31. 